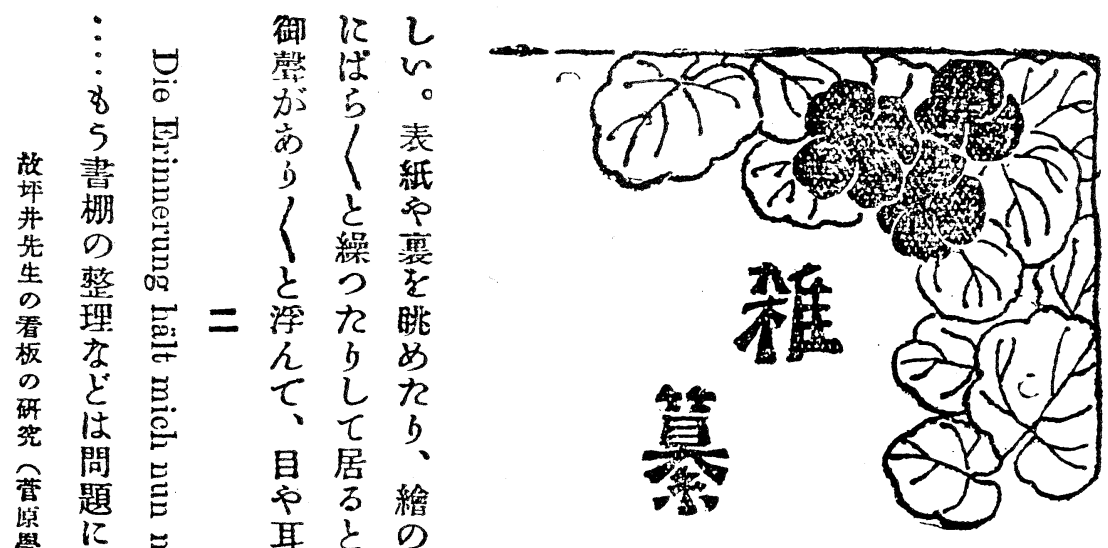

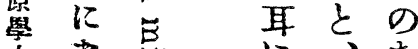

吉告に市西

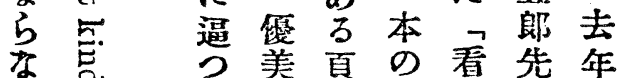

小党美頁 の看先年

て招古板生の

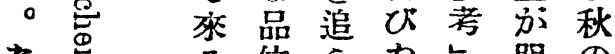

な正位 5 九明の

つ。西臭と治事

加要行 U 云三て

し 宓 万つか子十市

先方云本年方。

k.

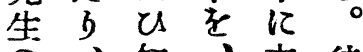

の、知、本徒

御本 万久鄉然

㰓の 2 し六の

市落振丁折

、口付 $b$ 目に

金をいての書

鉿右た手哲 棚

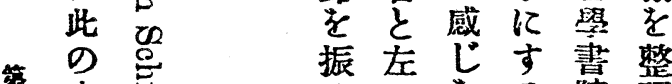

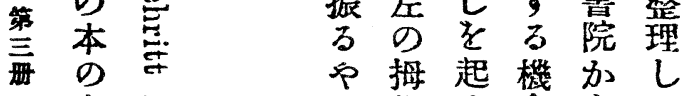

表

分 紙

5 指

なのせを出り

吾占

先腹る 得版、

告宁のた不

故

玶

井

文

先

學

生

の

菅 㲜看

原裀 板

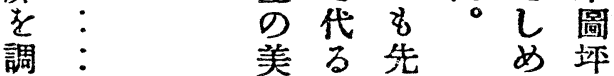

$士$

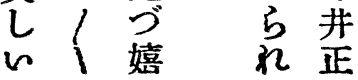

ネ: 


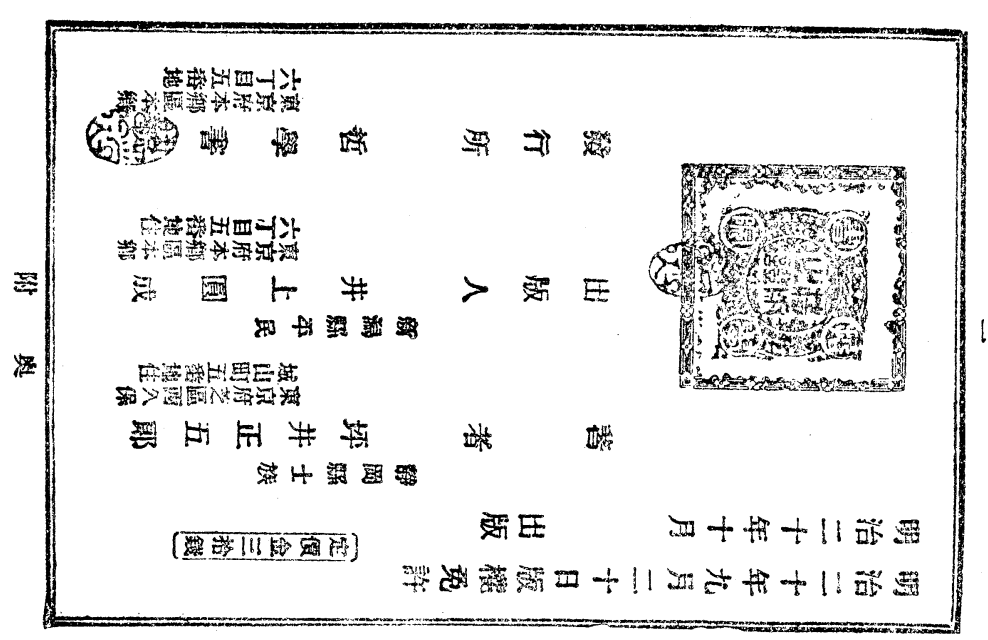

3

本

文

心

拾 理

础

究

1

L

7 第

b झ

并

奥 號

付

籍

糜 筮

告

苯

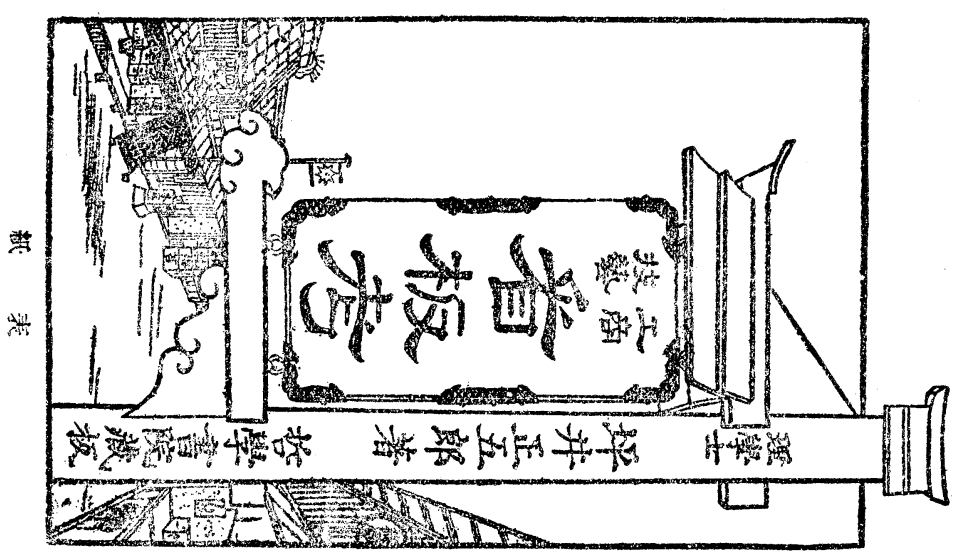

跳

め

to

$b$

5

3

明 第

治 t

泊 管

$\vec{十}$

年 元

玄

謂版第洋はるし紙此な㧼方組㭙し尋自第

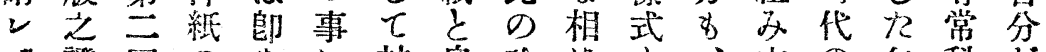

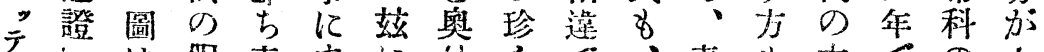

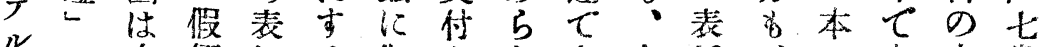

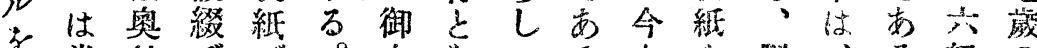

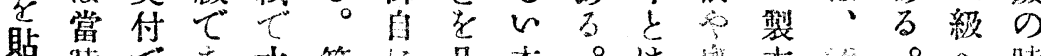

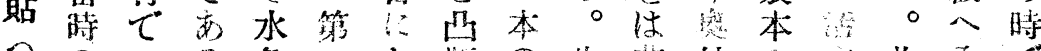

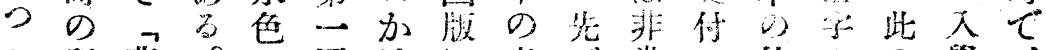

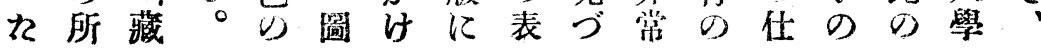




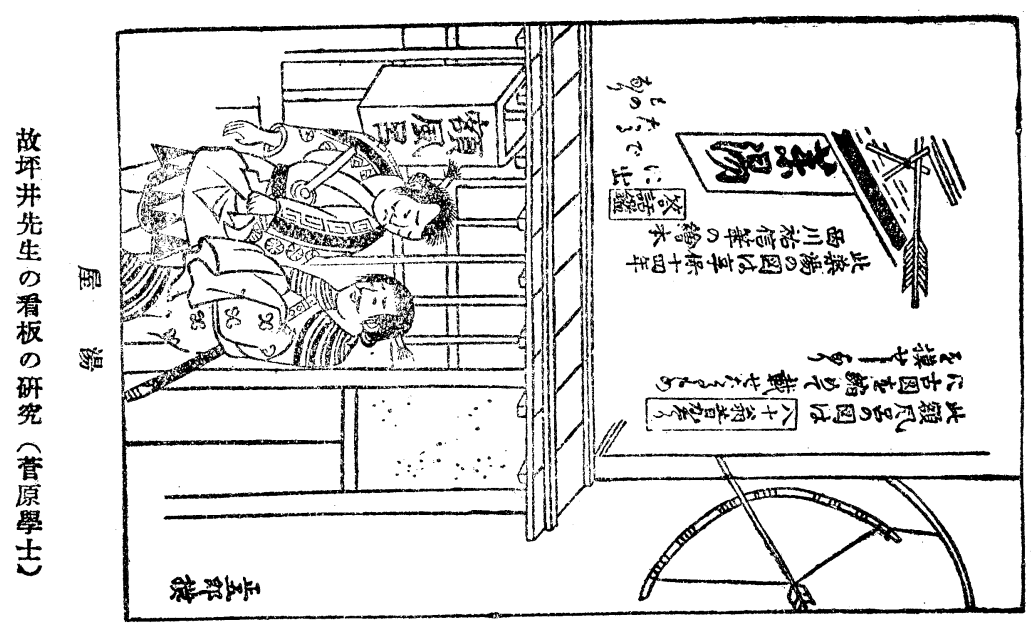

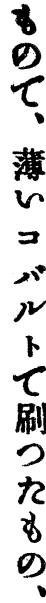

小

(1)

形

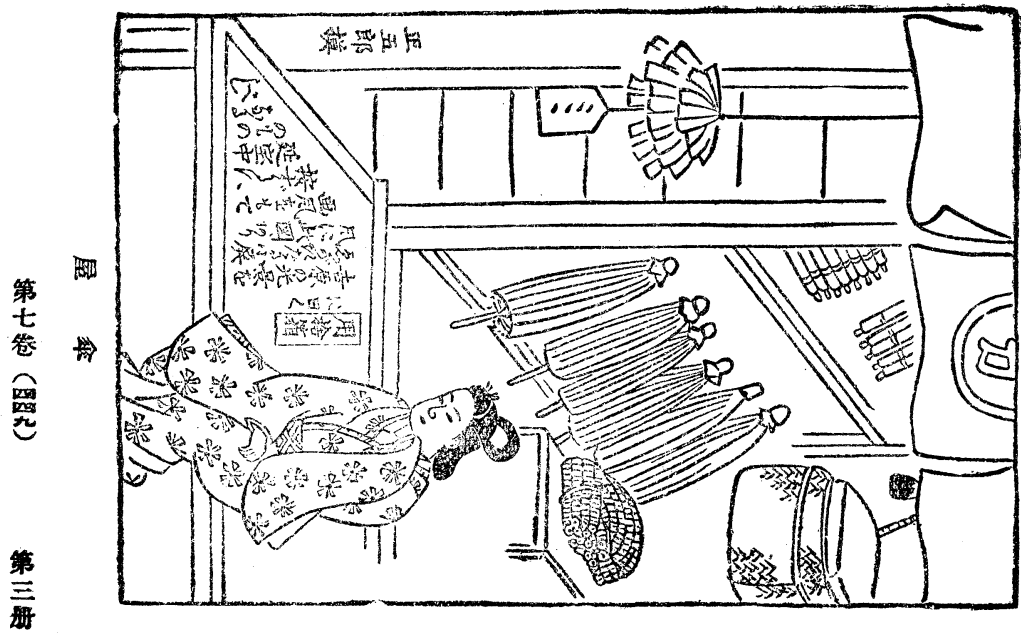

の

印

は

秦

L

b

朱

肉

c

あ

る。

公非文殊本气的にて的てはとの人

も常藝に㚣は特㱠、のるる。方類先

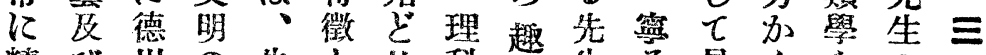

精ひ川の先と此科味生万見 5 の

通雜時造生云范の味の 江るの考專

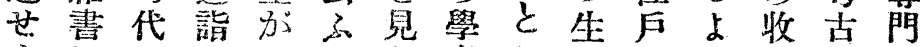

らにの、日べ者者し得子す得學の 


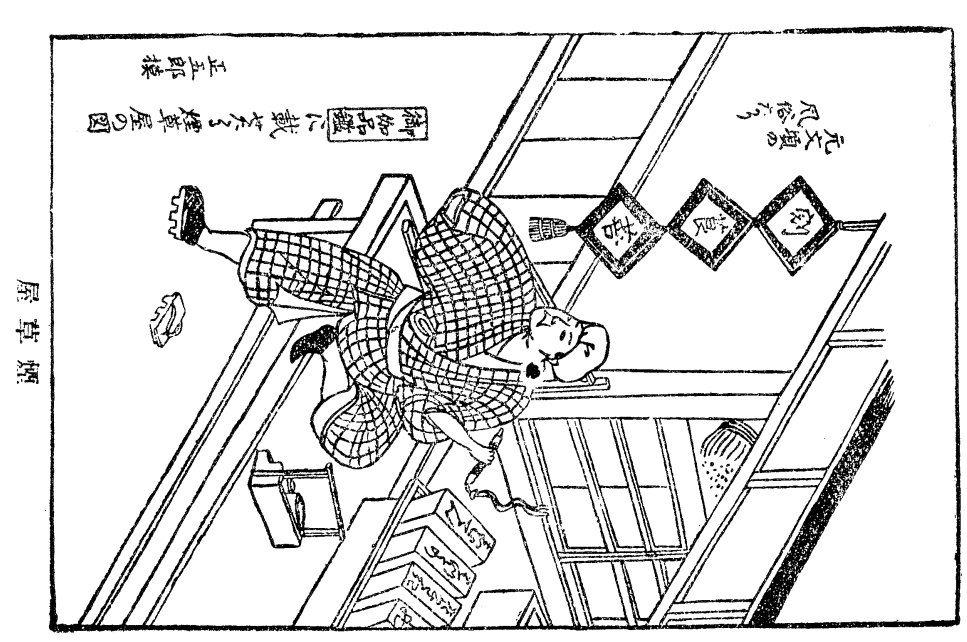

n

$\tau$

居

72

ह

云理

事 明

次究

あ 第

。

乙 杂

は

ᄀ 雜

看

板 篹

考

ए

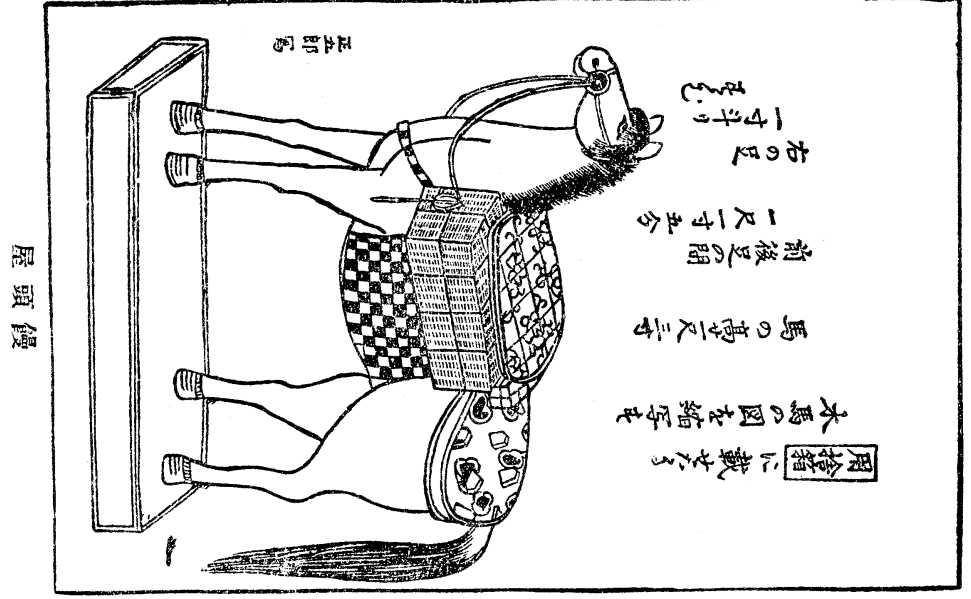

先

生

の

談

言向

†

州文 第

章 七

て 管

忍酎

分

l冖

䇲

事 第

をれ狂で讧常れ达てのの文今つ部 出

編う歌九局に。漂、輕はゃ分

し牛を先子良思は更妙、践の加言生

來 公

、の生的心的しにの黄のせ、文の

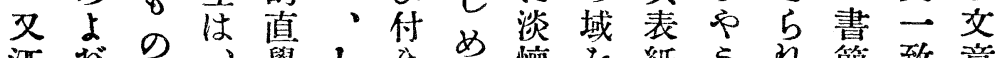

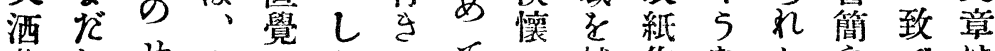

落れ也よ加のた越作なれたて

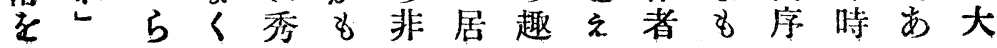




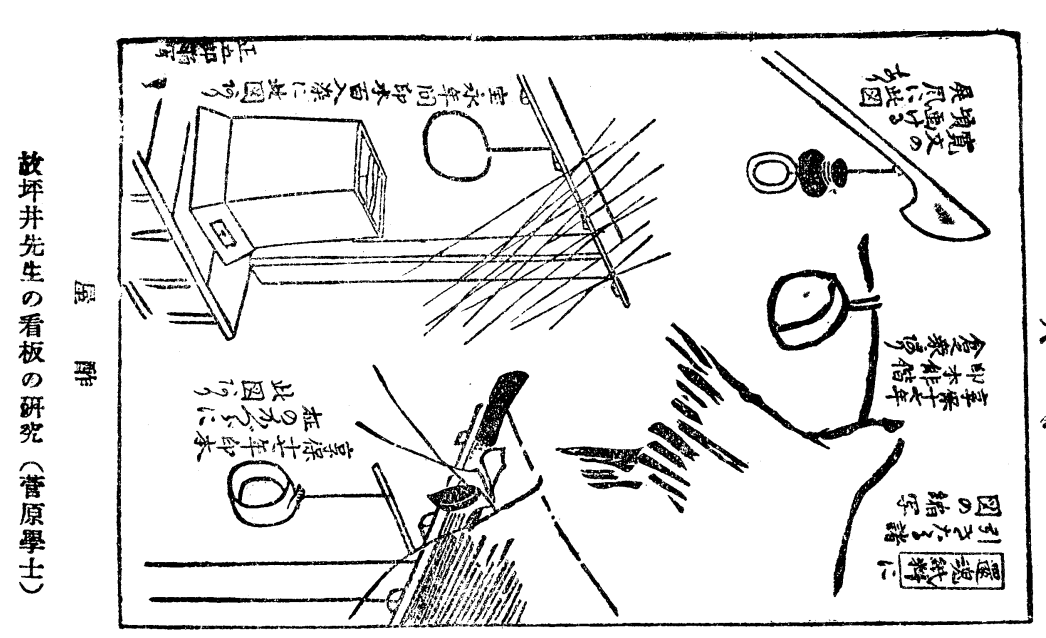

仰

$?$

b

n

ל.

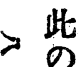

の

酒

落

は

生

承

D

江

戶

趣

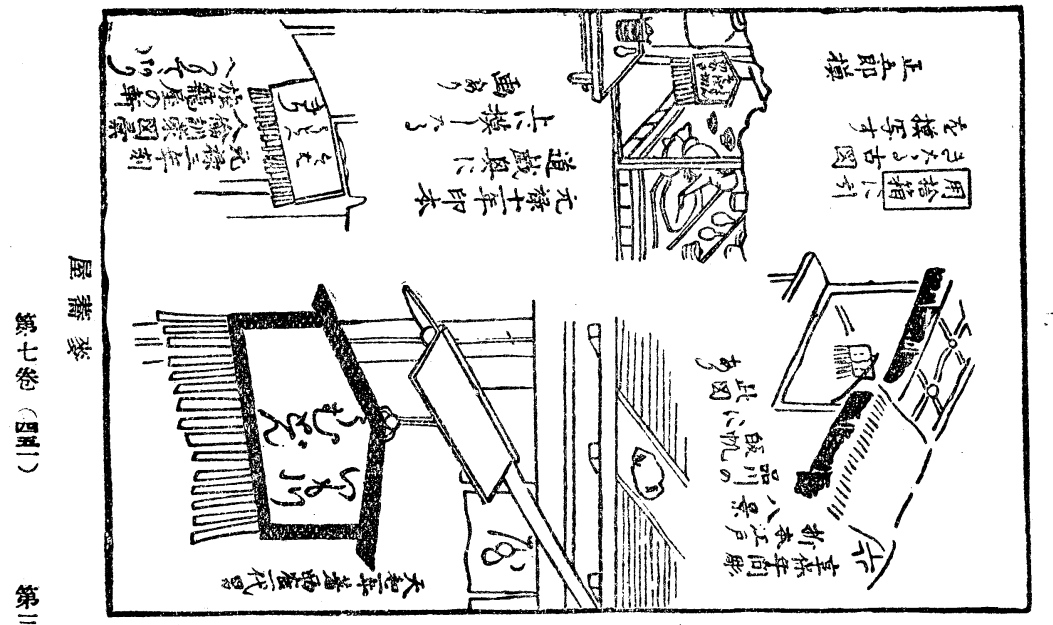

味

乘

D)

人

類

$\div$ 學

考

古

學

と

醇

化

さ

n

らの近のてては洋或 $ら$ 落し土出て

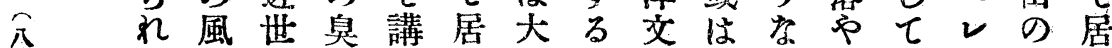

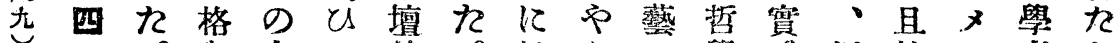
。を市の的。趣 5 の學感近執ン者加

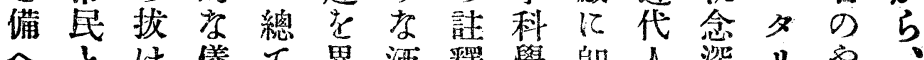
乞とけ儀て 異酒釋學即人深りや $\tau し れ$ 式にに落をゃしのい, 居七、的於しを要西九や酒に舍 


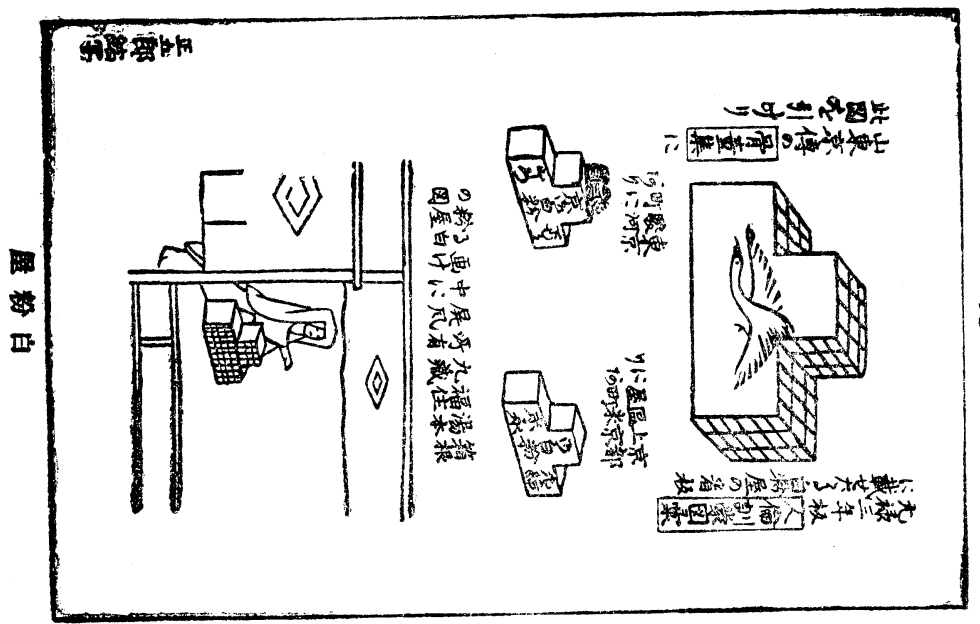

理

科

$\sigma$

學心

者理

云 研

* 究

过第

自立

分

子

親

類

格

の

人

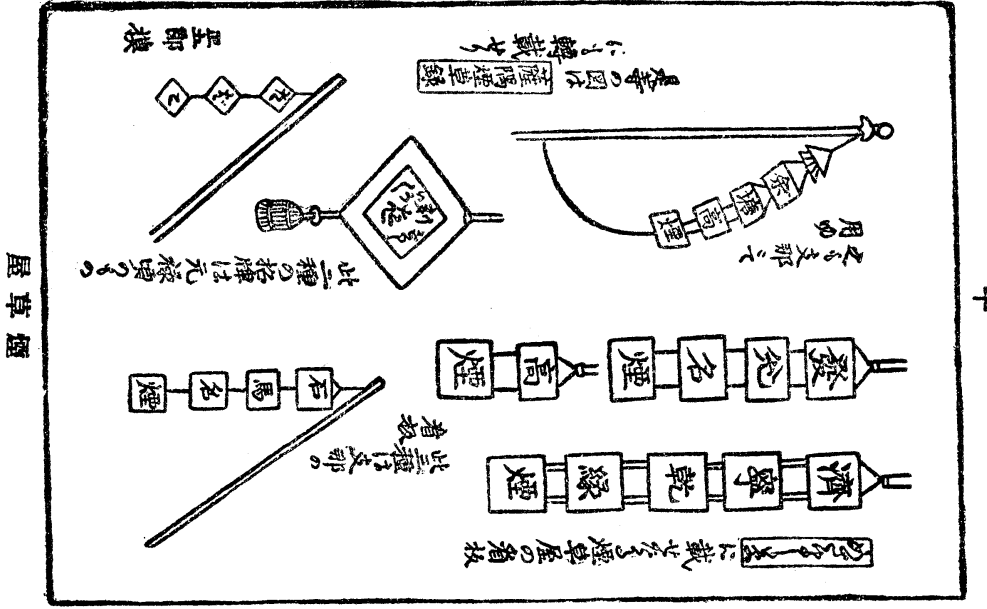

?

札

幌

$の$

農

科

大 學

\%

溒

吉

郎 第

के

乙的持日に文めら學は幼之强のあい、

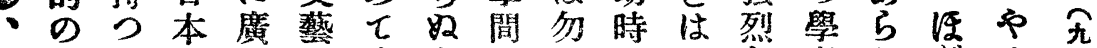

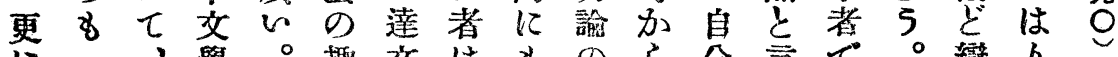

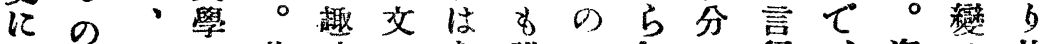
西殆に若味の誰乙知の行、海门比

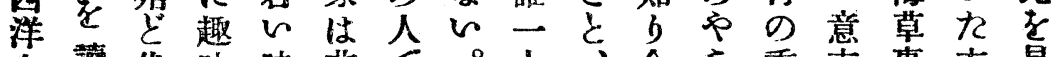
㚣讃代味時非 $\tau$ 。人合 5 秀志專方自

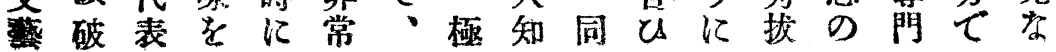




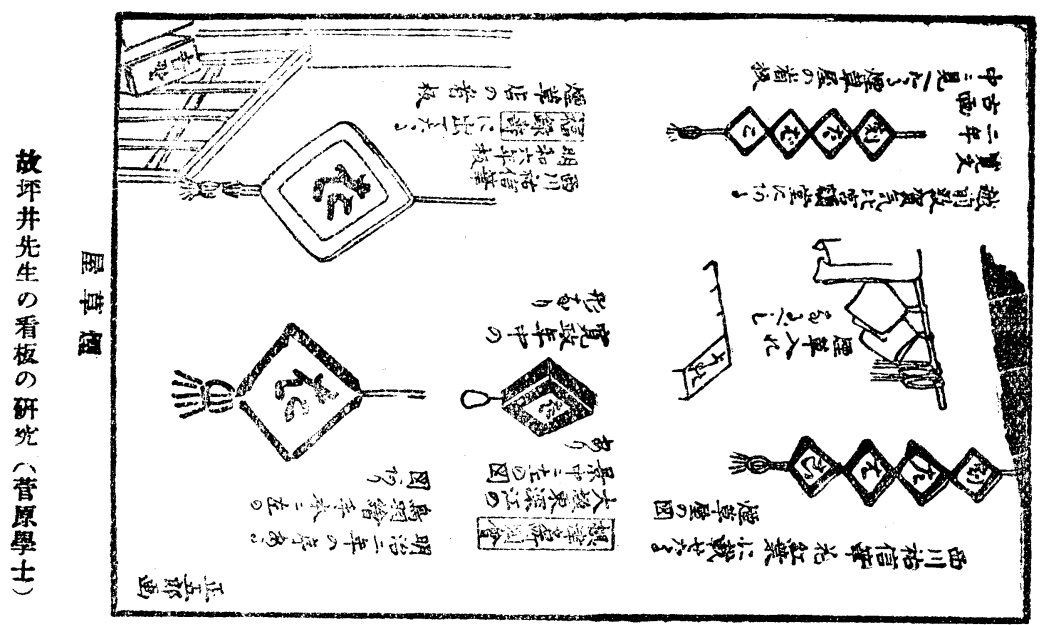

素

莀

11 先

$\tau$

居

。

管

$\tau$

左

物

學

的

人

$\overrightarrow{0}$ 然学

\section{$\lim _{0 \rightarrow 0} \infty$}

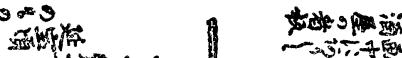

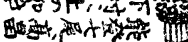

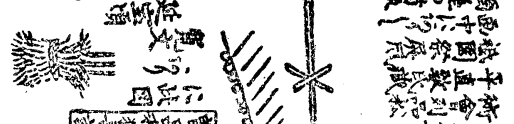

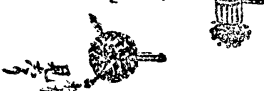

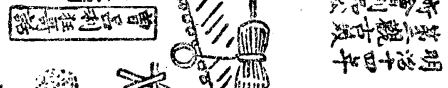

现

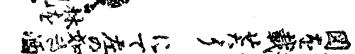

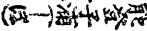

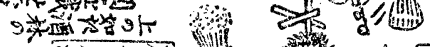

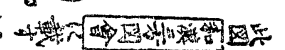

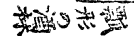
$x \rightarrow$

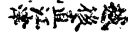

편 rad
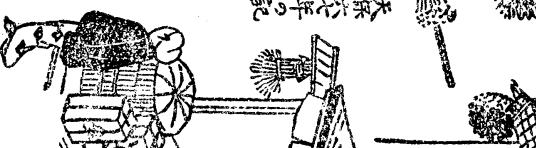

- 3 .

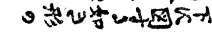

道

敬

ᄂ

tr

十著

は

昨

年

歐

洲

に

へべ生自に問人追スいい虽ス新威を居

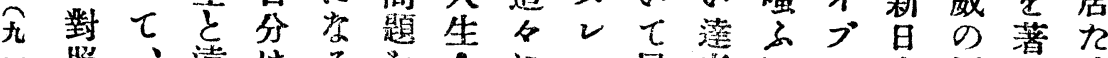

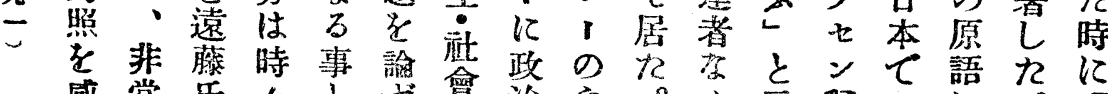

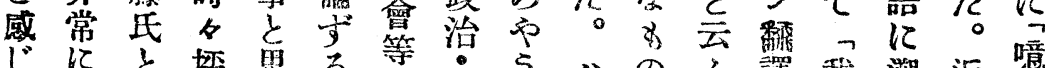

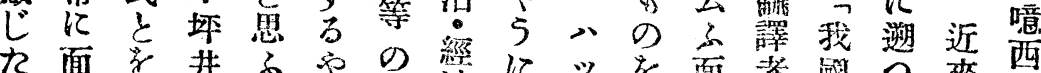

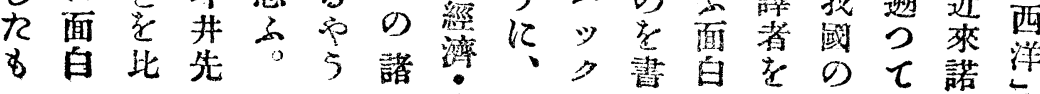




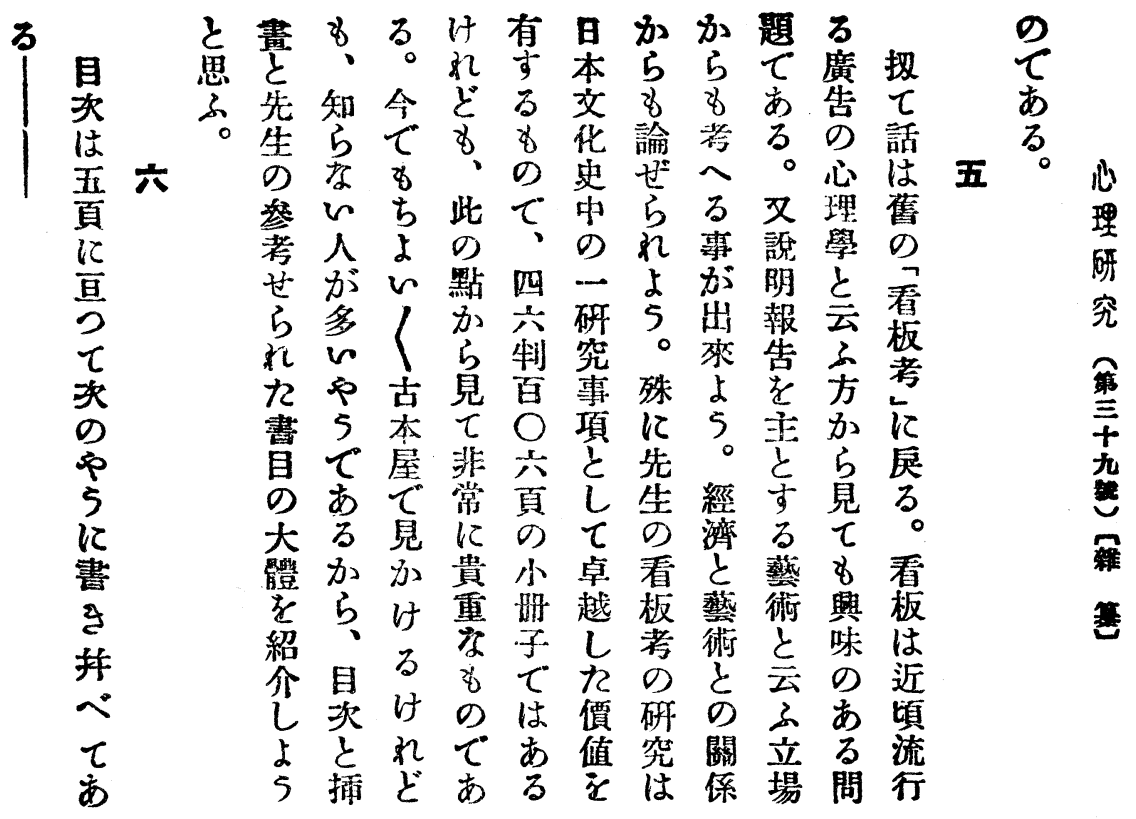

第 第 第 第 第 第 第 第 第 第 $\bigcirc$

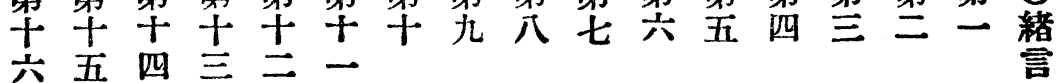

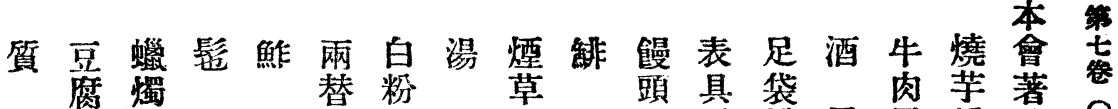
屋屋屋屋屋屋屋屋屋屋屋屋屋屋屋屋述

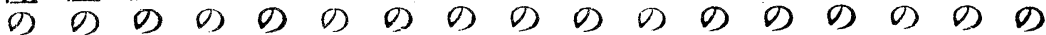
看看看看看看看看看看看看看看看看主 板 板 板板板板板板板板板板板板 板 板 意

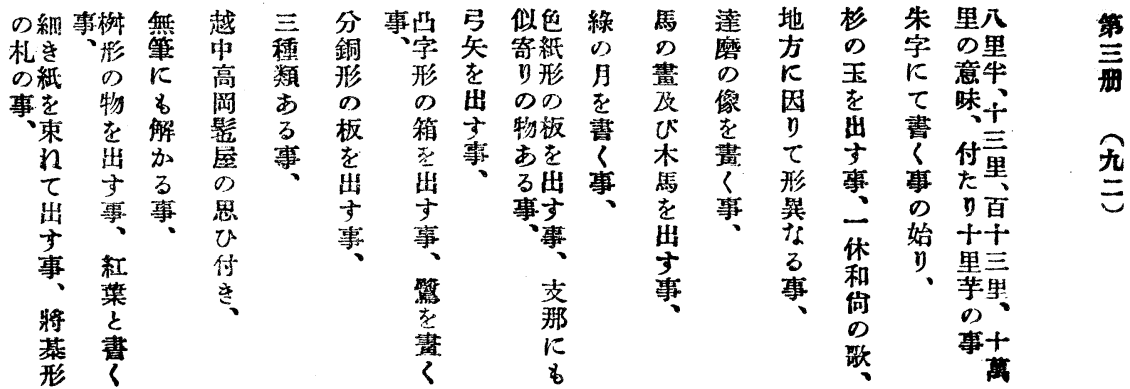


第 第 第第第第第第第第第

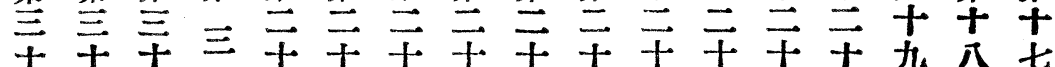
三三一十分分七六五四三三—

\section{故}

㙁

弗

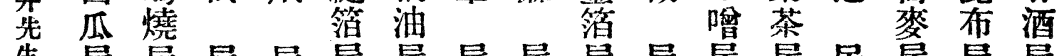

生 屋 屋屋 屋 屋屋 屋 屋屋屋屋 屋 居 屋 屋 屋 屋

の首の の

板看看看看看看看看看看看看看看看看

研板 板 板 板 板板板板板板板板板板板板板

茞

第

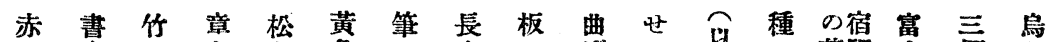

行㟟

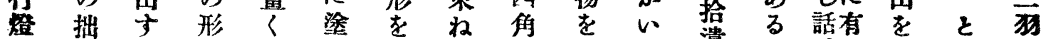

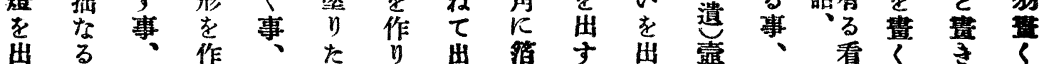

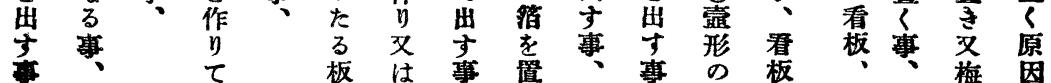

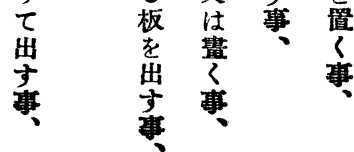

第 第 第 第 第第 第 第 第 第 第 第

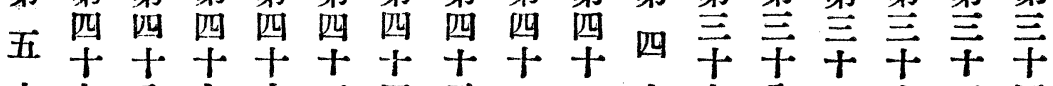
十九公七空五四三士口十无无四

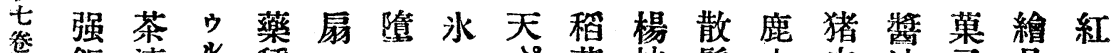
飯 漬 2 種 荷枝髮肉肉油子具

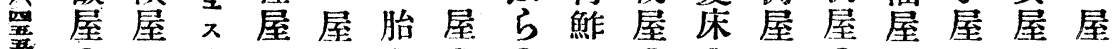
の

看看看看看看看看看看看看看看看 板 板 板 板 板 板 板 板 板 板板 板 板板板 板 板

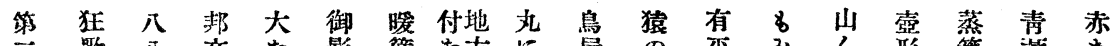

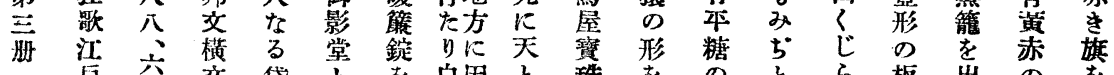

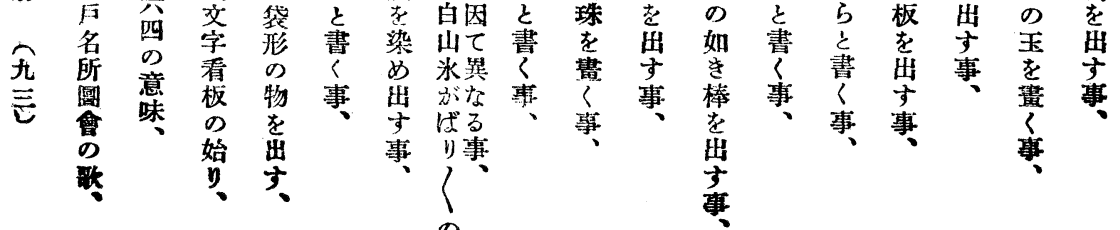


種落てはは

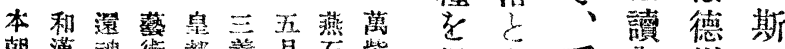

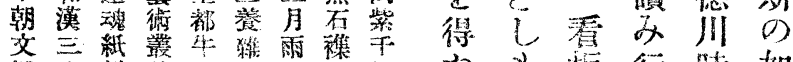

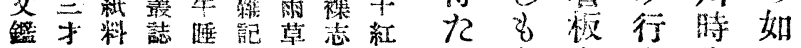

间

江京東江猿我和七人

す 路尔が名士偷

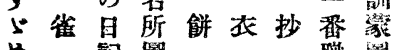

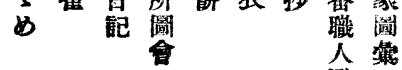

歌

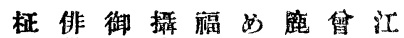

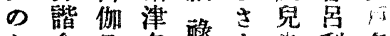
加會品名脉ま落利名

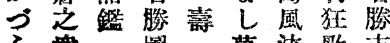

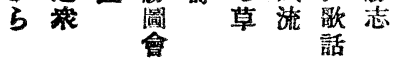

有教文代く

らに宣 $の$ 豐

5 揭 ら㟟當

けげ、籍 な

れて 先少 万

どあ生ら看

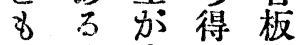

、分直らの

そを接れ種

し拾にれ類

$\tau$ U 參 के

次出䓔口研

のし世究

やれらあ究

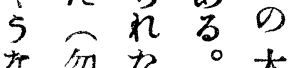

五論与自部

十見方分分
第

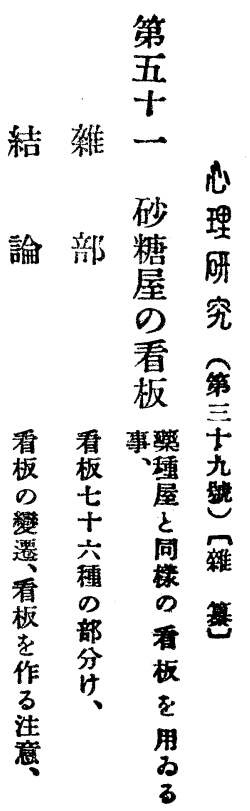

のらど、出出䈍看

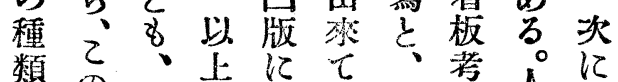

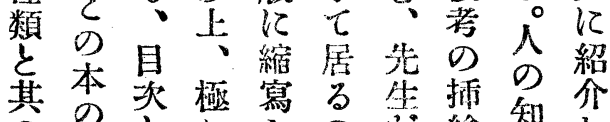

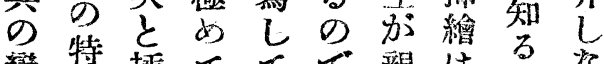

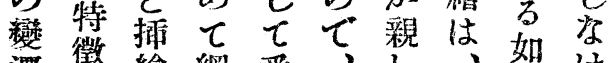
遷徽繪綗悉、筧: 如计

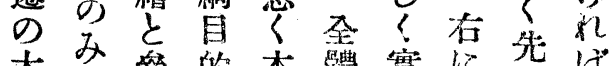

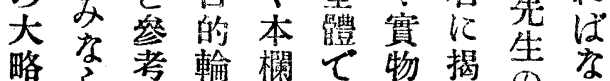
略考輸欄て物揭主尔

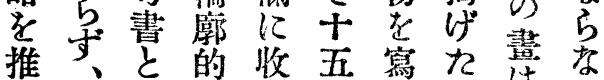

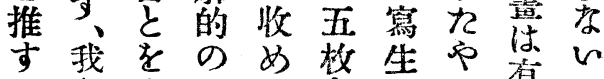

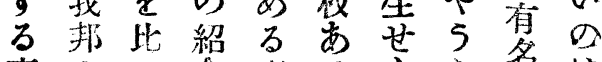
事口留事方兮名は 加看ててに。古本本 出板見はし之江萻曋

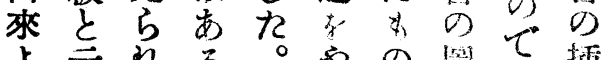
小云れる。占の圆市插

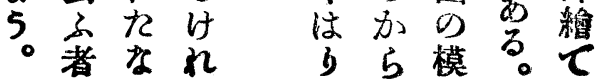

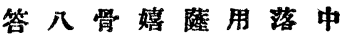
話翁董笑隅捨穗南

鑑暮集䂓草箱集俗

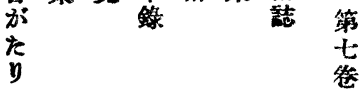

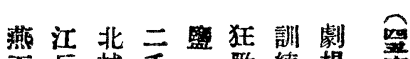

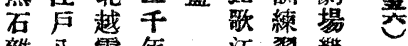

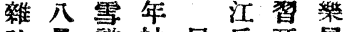
誌景譜袖尼戶耳屋 名扎阔

圆取

$\stackrel{\text { 第 }}{\text { 舟 }}$

道一野道梅火百

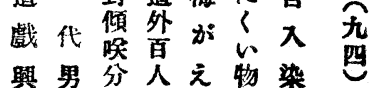
色羙 ? 


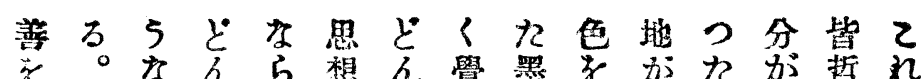

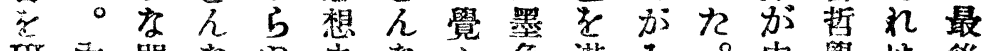

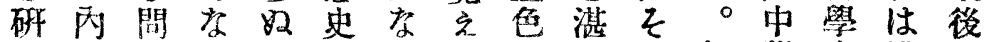
究田題洋。上本江分的學書權に

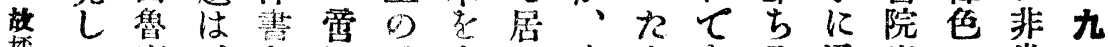

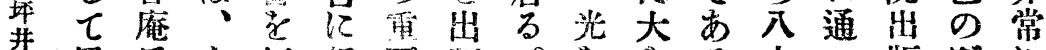
先居氏や何哲要版哲を导六つ版され

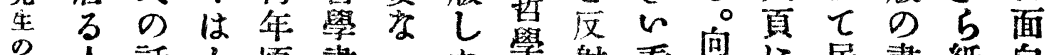

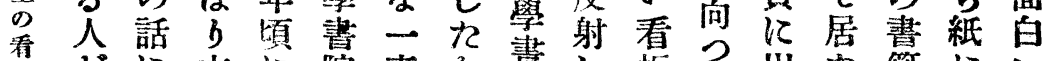

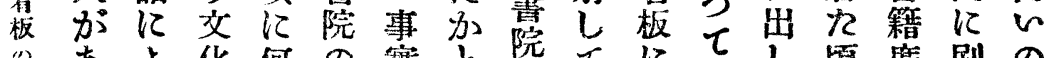

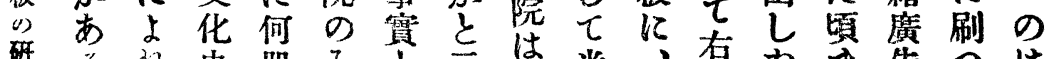

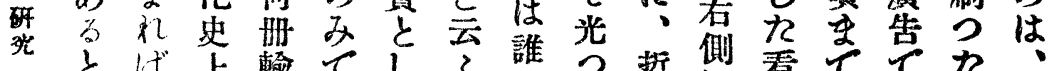

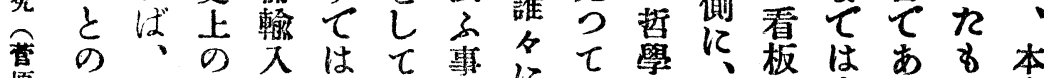

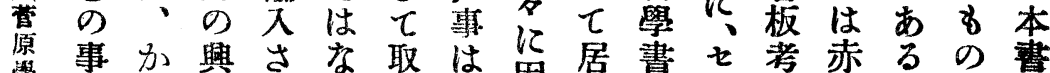

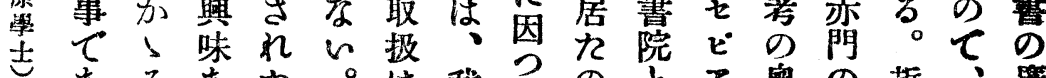

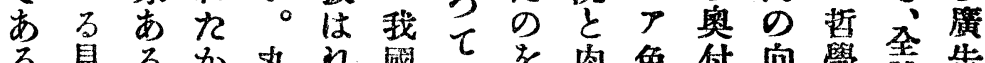

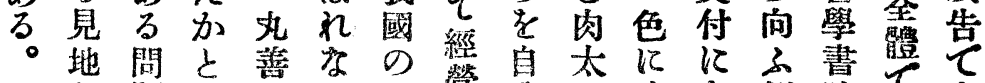

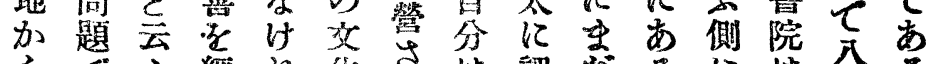

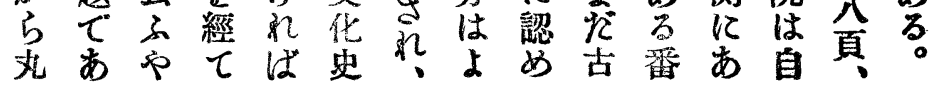

\section{錢價心の最のる理潹因講さ行}

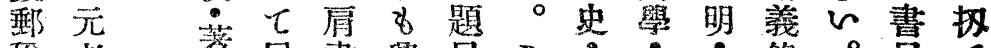
稅老讙居書興慁乙妾國宗錄。自乙

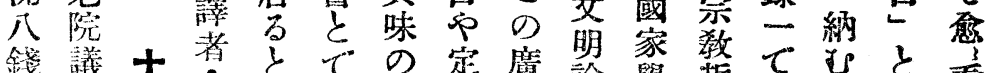

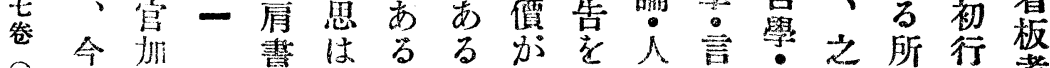

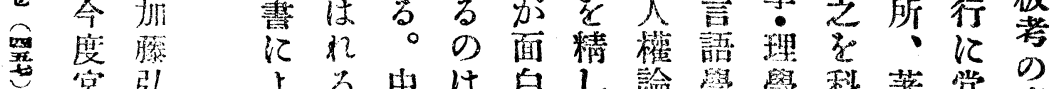
宫弘よる中は白し諭學學科著堂の

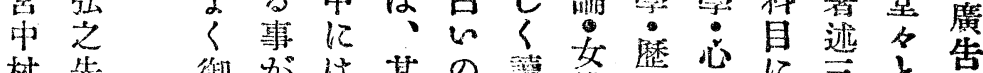

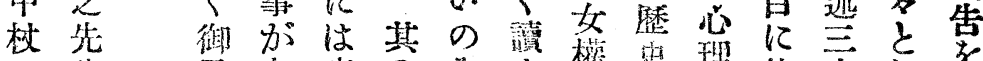

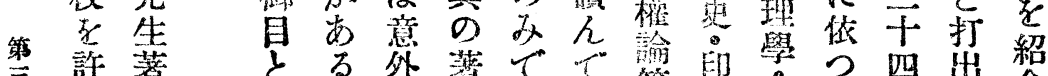

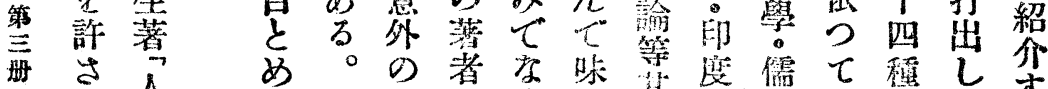

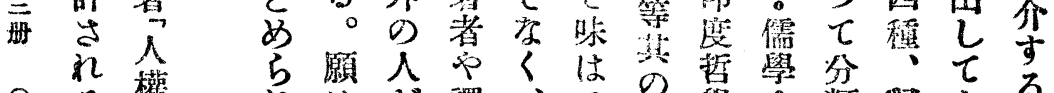

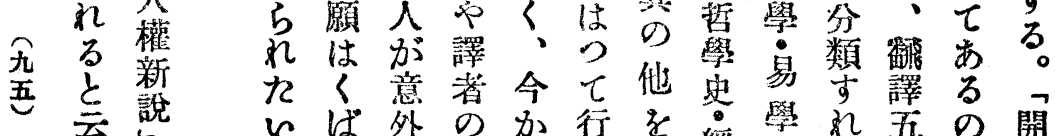

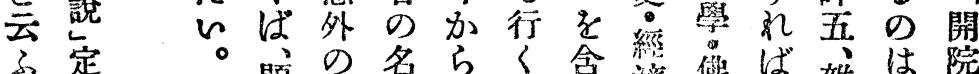

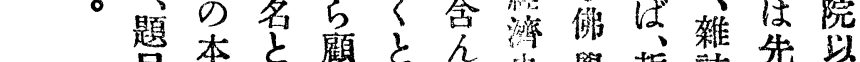

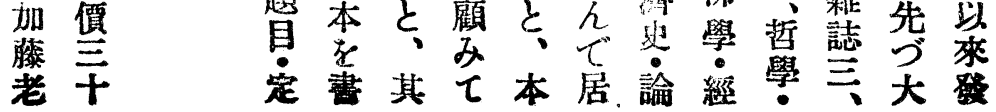




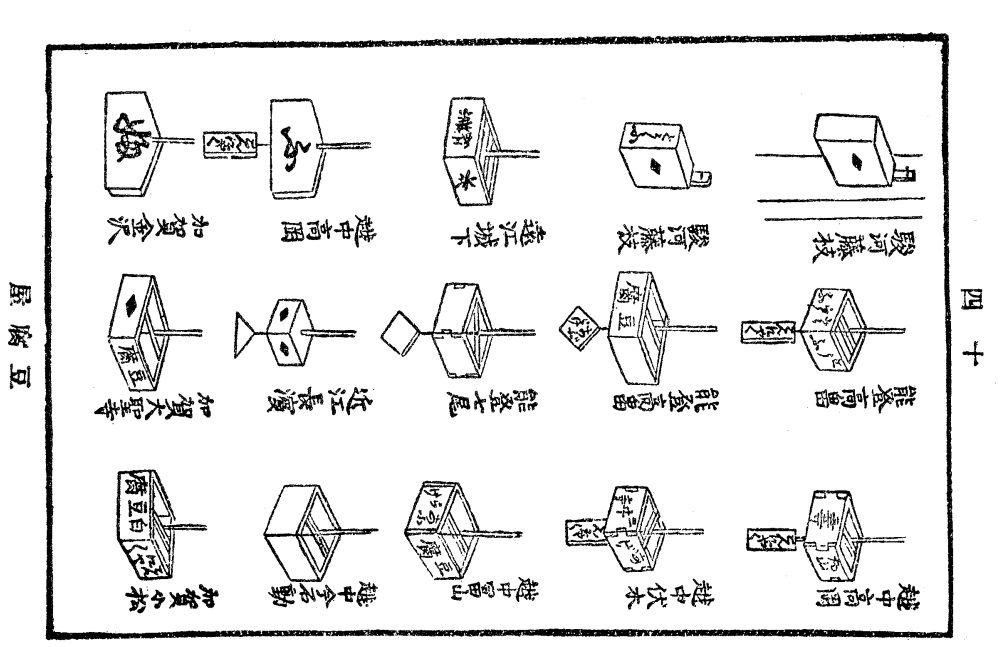

先

生

の

事

で心

直理

万研

力

5 究

元 第

老

院

議

官

の

局

書

8

尤

8

な

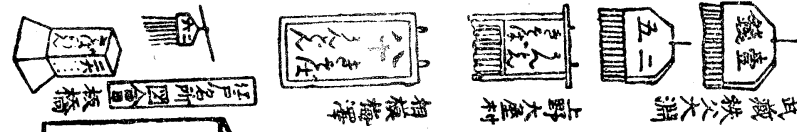

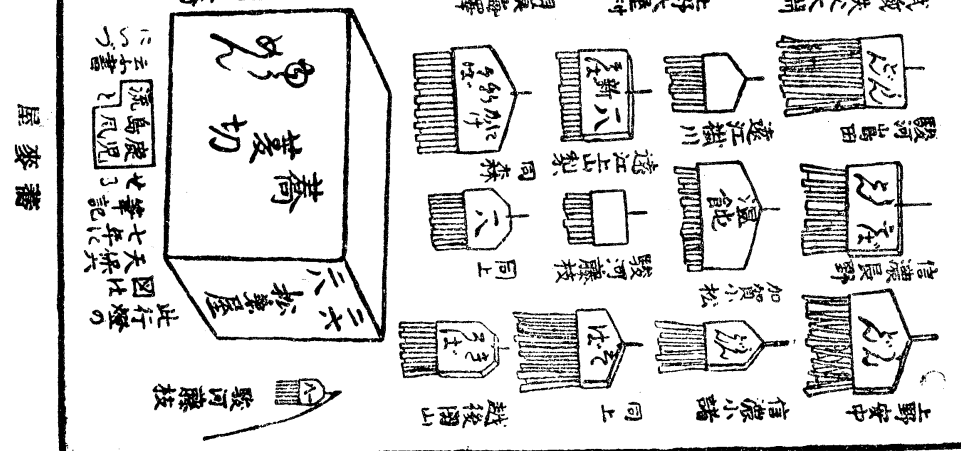

事

$\tau$

市

5

5 第

大 荧

藏

留㹂

䛨

启

局

長

從等

位

はるに上邊肥さる学夥名共定印渡无

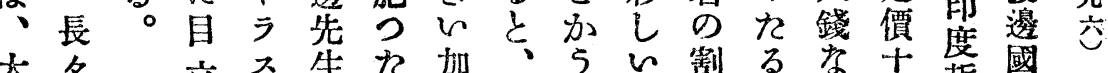

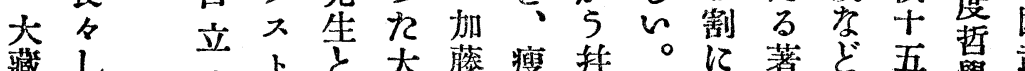

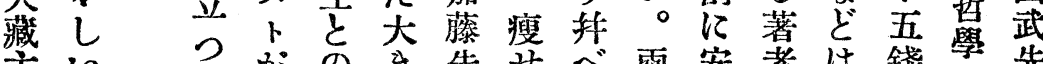

主

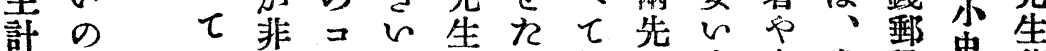

官て 桃常ン渡と見生事書堂棁史著 


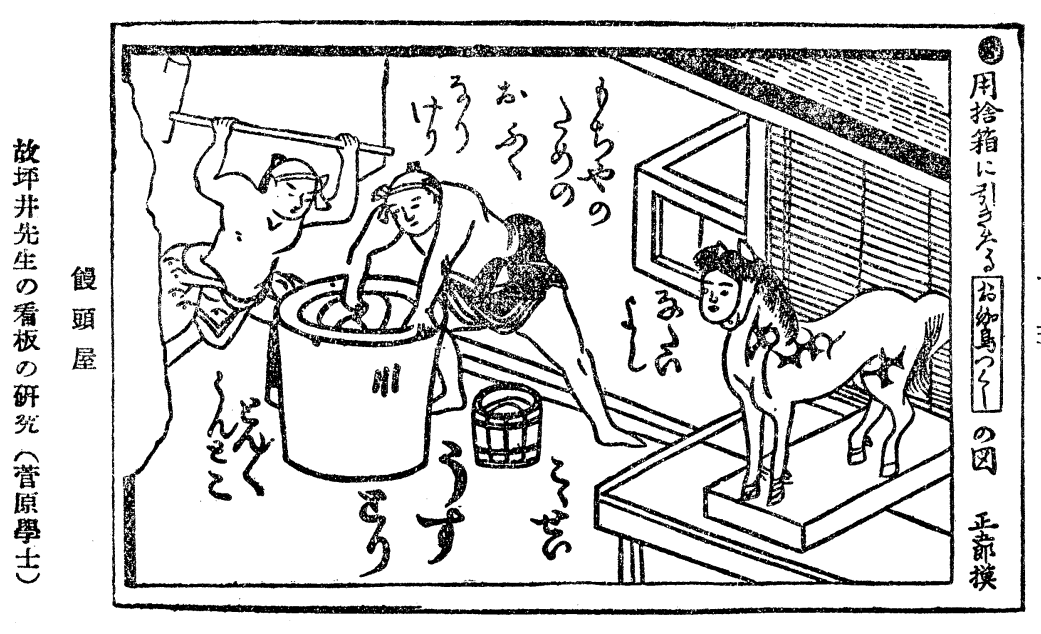

萧

海

軍

敎

授

交

學

+ 声

王谷

芳

郎

先

生

述

東

京

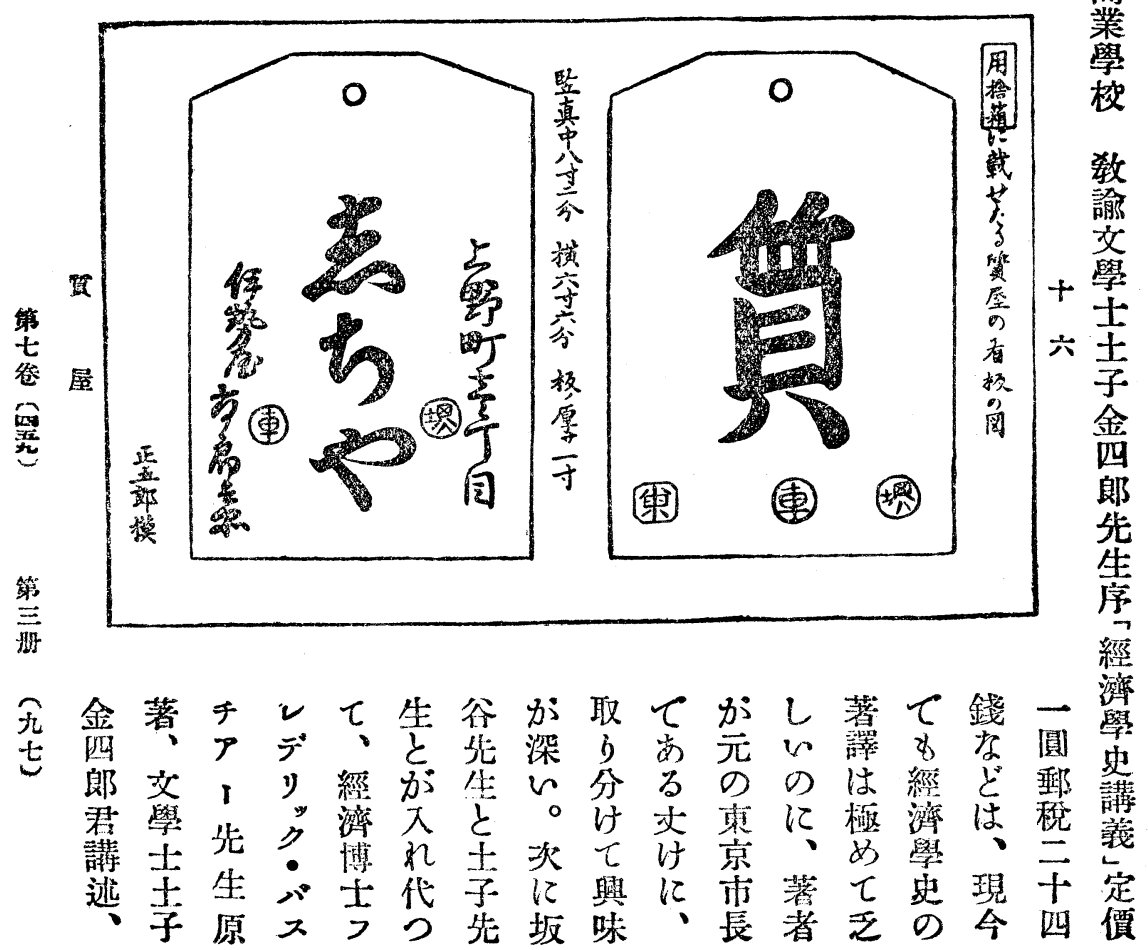




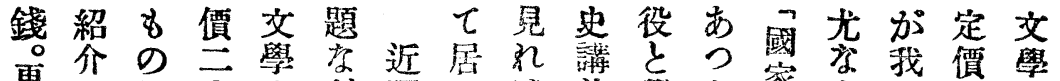

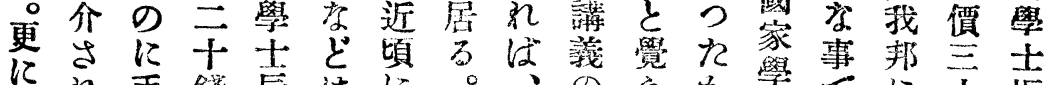

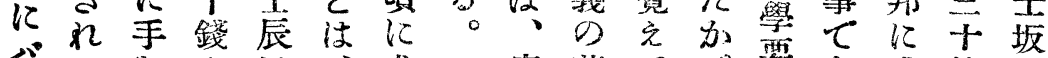

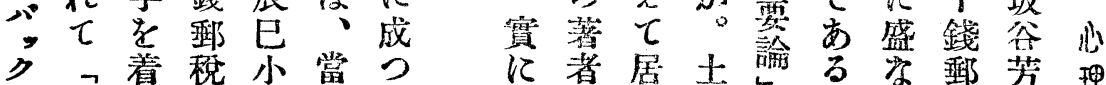

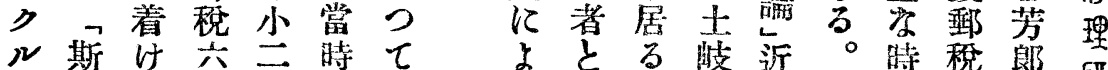

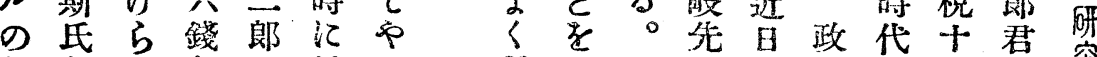

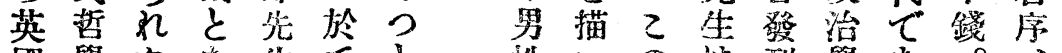

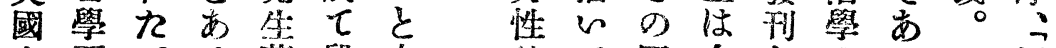
交要。る著段少 明義ス。西名し 史恣唇西出盛 定ン等洋版骨 抄價 サ先杲さ成 譯兰、生李れ。

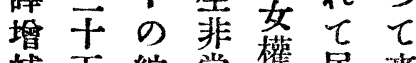
補五綜常權居乘 批錢畣江龩艺。加 評郵哲大患。婦 导税學学患郎人 的て國今とのう個經

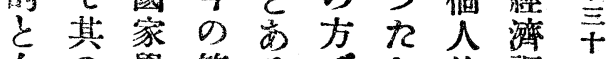
女の學第るて加的調㠰

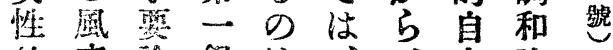

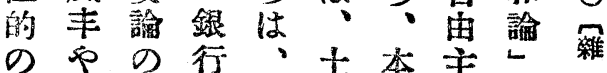

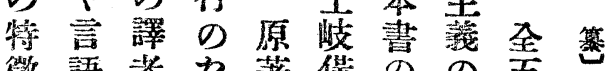
徽語者九著㣴のの五 をとしは先出經册

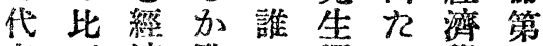

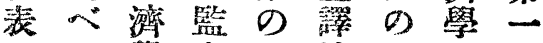

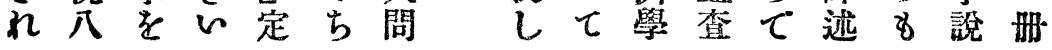

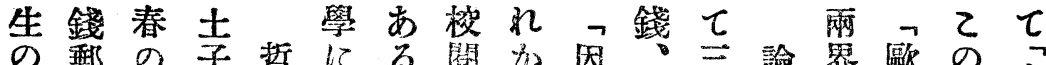

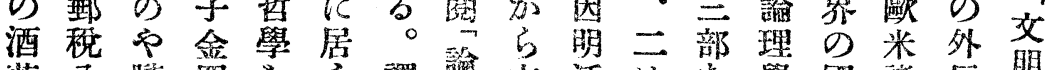

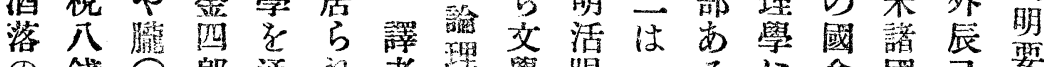

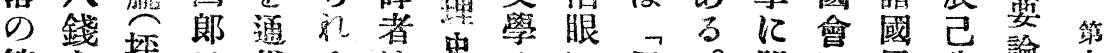

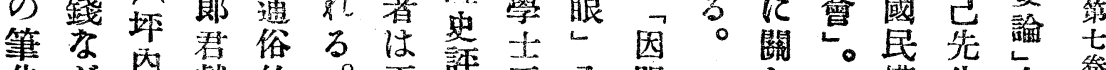

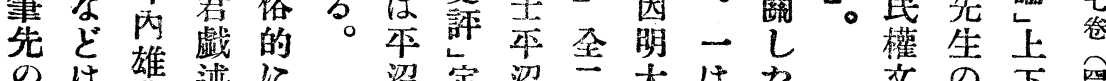

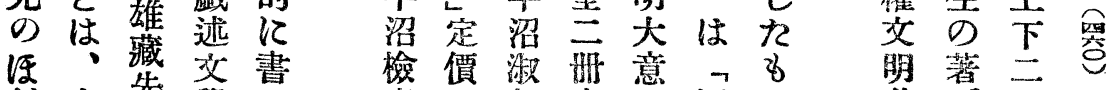
ぞ本先學兵事等郎定总因の共灾

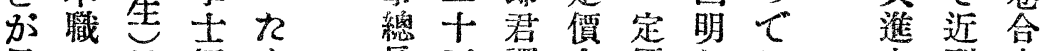
思の君坪的長五譯金價初学茰刊本 ひ話践井のの钱述公十步、穆定第

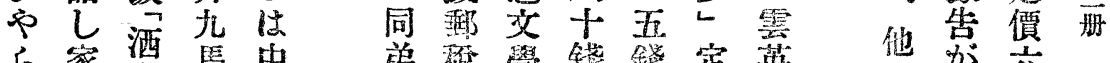

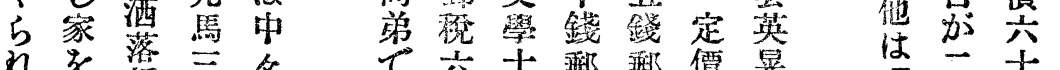

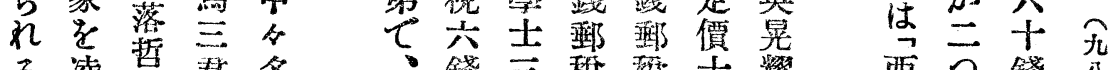

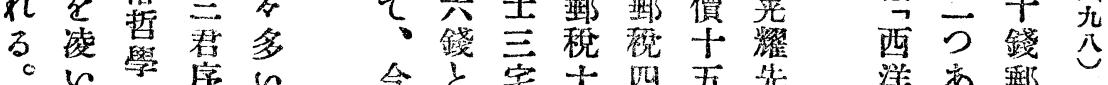

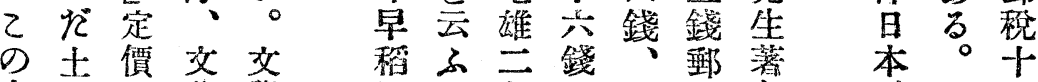

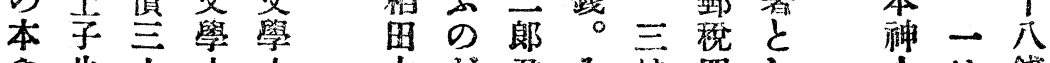
中先干士士大加君をは四し人は錢 
云る几錢定著士錢定二先交價著安十㒸 子。く價哲杉。價哲生學分哲的瀻學

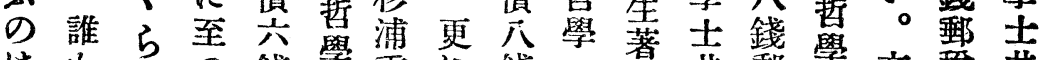

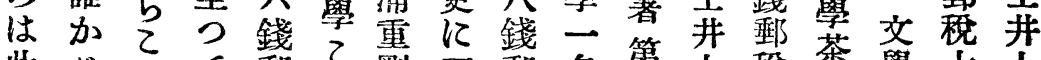

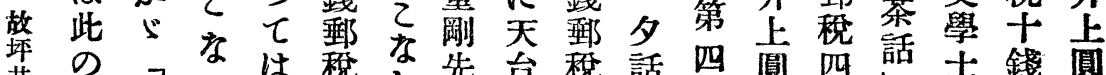

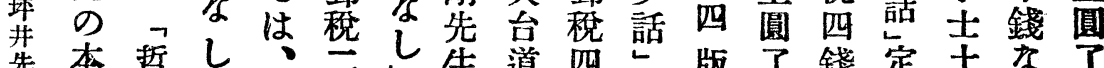
先本哲し、气生道四版了錢定土拓了 生

看事 殺に

看てし せ 研离息 究。聞 U 菅当切 原違つ 声

第

t序編論

坴論态定

突定現價

價は三

四市十

十九錢

第吾 8 郵

第 錢 の 税

再郵 万六

稅 し 錢

无十

旮

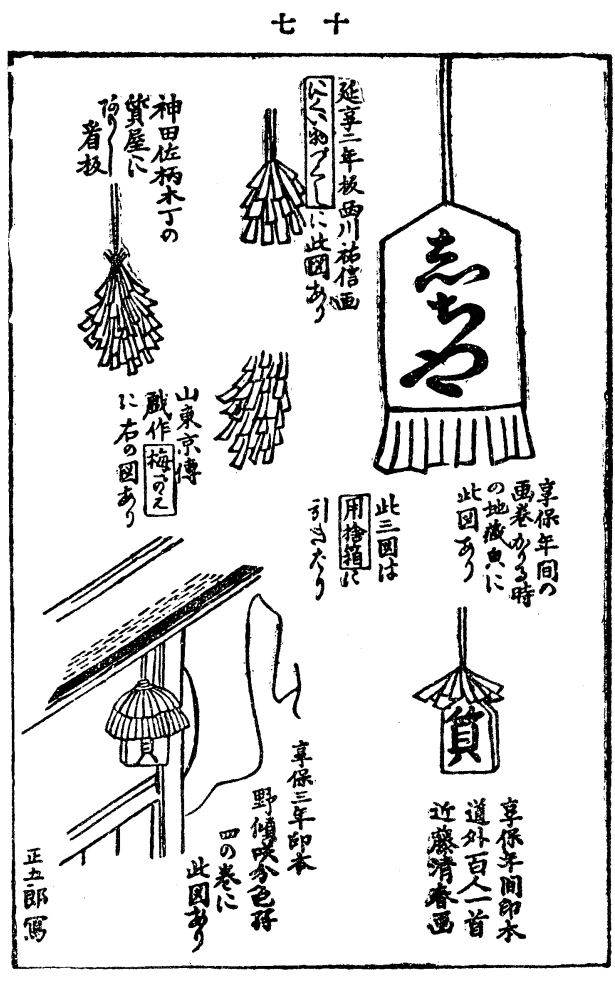

屋算

子 と先

笑は生

面高著

君尔哲

序方學

络南道

士

の

ゃ尔

< क

万の定

らは價

君皆三

畺 告

情安文

。三 學

又つ士

交出至

學 $\tau$ 宅

居雄

棚当。郎

- 一 君

郎は著

先宗字

生委

著教徨

及統筆先 3 近は定哲

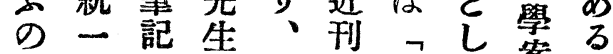

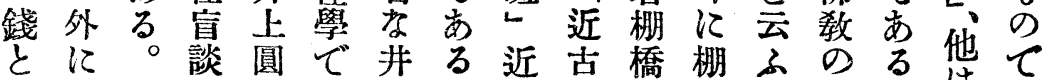
先 2 了は上。利儒一橋方道名は近 佛生の第君、先先林郎大涂口佛刊

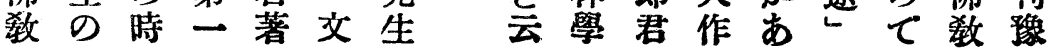


時は哲評郵子。號召向聂九公活

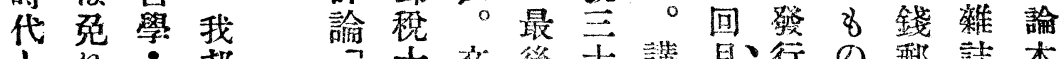

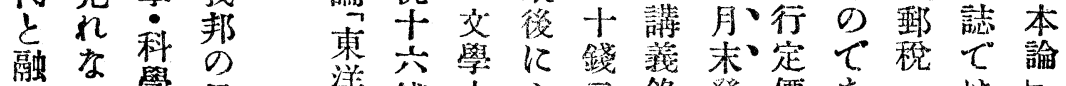

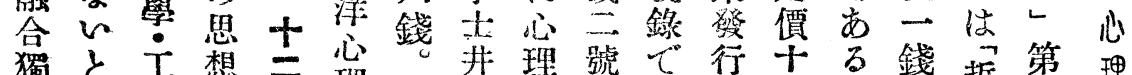

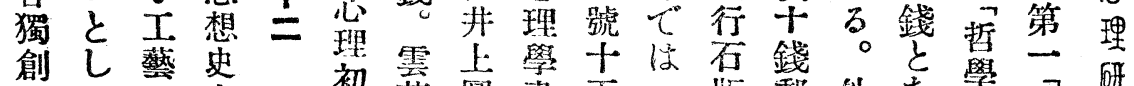

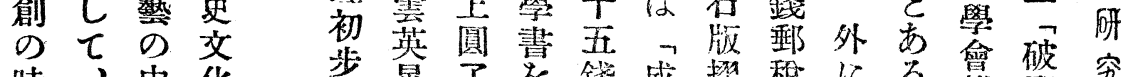

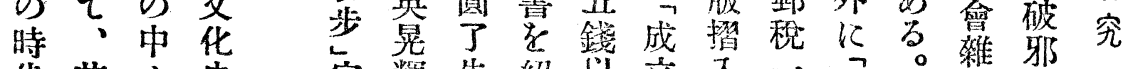

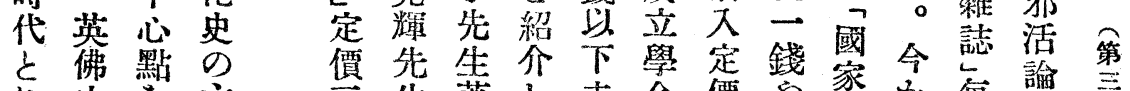

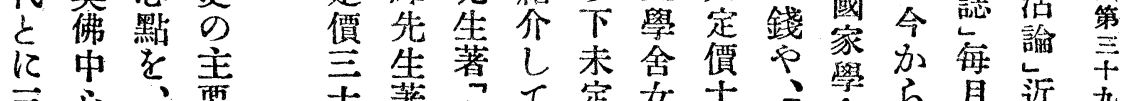

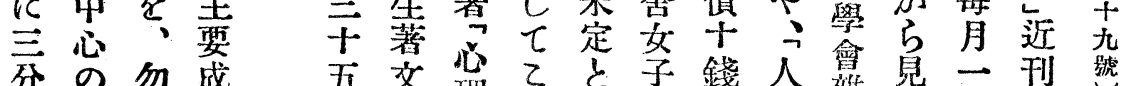

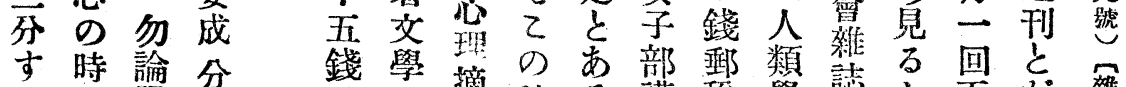

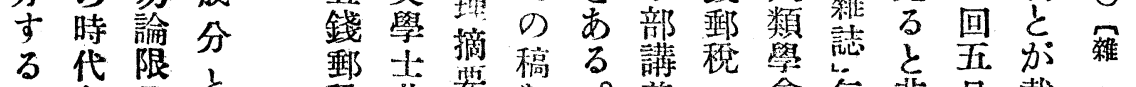

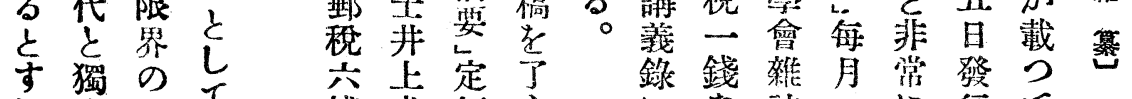

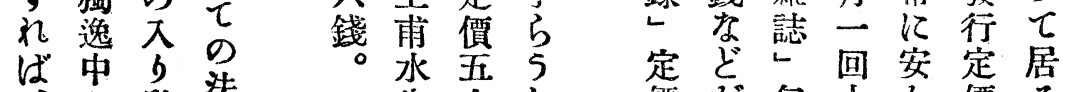

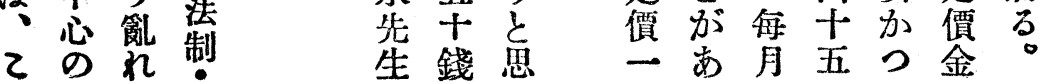

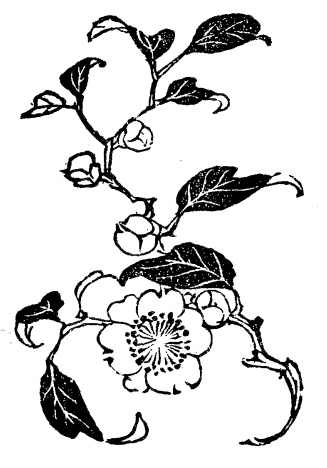

〈三心思黄占心竞庵 年理れ他る理文告

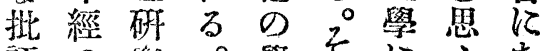

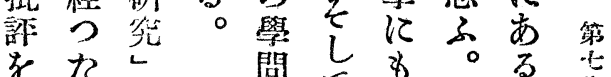
受㭙中 閏元占。方壱

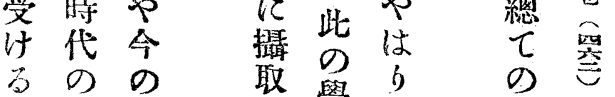
事人時学學右本

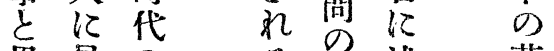
思見のる茏落

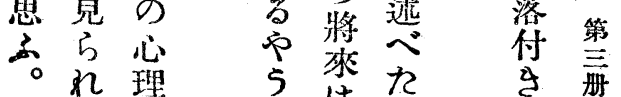

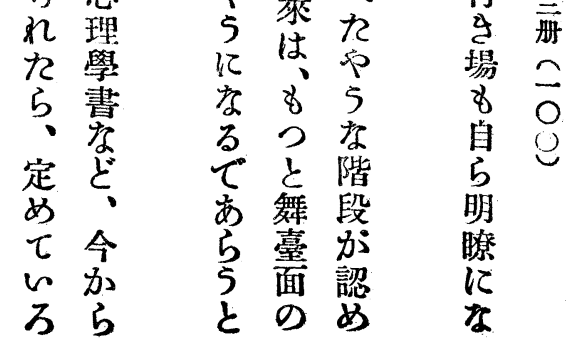

